\title{
Positional goods and the underfunding of public health
}

\author{
David Hemenway ${ }^{1}$ (D)
}

Accepted: 26 June 2021 / Published online: 7 July 2021

(c) The Author(s), under exclusive licence to Springer Nature Limited 2021

\section{Dear Editor,}

An ounce of prevention may be worth a pound of cure, but that is not how we prioritize spending in the United States, where public health remains the poor relation of medicine. In this letter, I briefly summarize some of the reasons why prevention is underfunded relative to curative care and then present a new argument, for the underfunding of both public health and medicine compared to many other goods and services. The pandemic has exposed the underfunding of public health in America. Indeed, the lack of a robust public health infrastructure and our inadequate government response to the virus appear to be responsible for the unnecessary deaths of hundreds of thousands of Americans [1].

There are many reasons why public health (prevention) tends to be underfunded relative to medicine (cure) [2]. Four forces for such relative underfunding are: (1) Public goods. Unlike medicine, which can be provided privately, public health initiatives are usually collective goods, which the free market tends to undersupply. Public health measures such as sanitation and food inspection require public expenditures. One of our political parties has made it a core tenet to oppose most taxes and regulations; (2) Future benefits. Unlike medicine, which often provides immediate help in reducing pain and disability, the benefit of many public health measures are far in the future. Politicians correctly understand that their administrations will bear the costs, while the benefits may be reaped on someone else's watch. Politicians prefer to spend money on activities for which they will receive all the credit. (3) Statistical lives. Unlike curative care, which treats identifiable patients, prevention deals with statistical lives. Thus, most people do not recognize when they are helped by public health measures. If they do not get sick at work (because of air quality improvement) or don't get run over (because the walkway has been separated from the road), they aren't inspired to reward public health institutions. Compared to curative medicine, there are few "grateful patients" to provide financial donations; (4) Active opposition. Public health measures often require societal change. These measures meet opposition

David Hemenway

hemenway@hsph.harvard.edu

1 Harvard TH Chan School of Public Health, 677 Huntington Avenue, Boston, MA 02115, USA

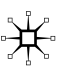


not only from "tradition-bound resistance" [3] but from powerful existing special interests who may bear financial costs (e.g., the alcohol, tobacco, firearms, automobiles, coal, and oil industries). By contrast, existing special interests (e.g., pharmaceutical firms, physicians, nursing homes, hospitals) often support increases in resources for curative care.

These reasons point to the relative underfunding of prevention; in addition, for the past half-century, economists have made the added claim that medicine is probably overfunded. A main reason for the overfunding is the "moral hazard" aspects of insurance. When someone else is paying, patients will demand high quality care and consume too many beneficial but low value services. Both the individual providers and the individual patients push for what has been called "Cadillac medicine." Here I discuss an important additional force for the underfunding of public health - and also curative care-relative to other goods and services. That force is the issue of "positional goods." While the concept of positional goods has been discussed continually in the economics literature for more than 120 years $[4,5]$, it has not been widely incorporated into policy planning. Neglecting the importance of positional concerns can lead to increasingly inefficient policies, since positional goods grow in importance as societies grow in wealth.

In traditional economic theory, goods and services are bought solely for their functional utility. However, many, if not most, goods are partly "positional goods," as their purchase or use can display or improve our standing, position, status or power. The competition for standing, status, position, and power is largely a zero-sum game. If someone was to rise, someone else has to fall. In a consumption race, from an efficiency standpoint, too many of our scarce resources are being used for positional goods and thus too few for non-positional items. Few goods are either completely positional or non-positional, they lie on a continuum. Less positional goods include public health measures to reduce illness and curative medical care [6, 7]. Shifting resource allocation from goods and services that are more positional to those that are less positional-such as public health and medicine-could enhance social well-being.

An understanding of positional goods provides yet another reason why public health tends to be underfunded. It also means that economists may be too quick to assume that our society is overspending on curative care. It is crucial for society to recognize that public health is underfunded, along with the systematic factors that create the underfunding. We have to understand that without fundamental changes, the underfunding will continue to cause unnecessary hardship. We need long-term strategies to overcome the barriers and provide adequate support for public health. A more efficient allocation of society's scare resources would lead to longer and healthier lives worldwide.

\section{Declarations}

Conflict of interest On behalf of all authors, the corresponding author states that there is no conflict of interest. 


\section{References}

1. Council on Foreign Relations. Improving pandemic preparedness: lessons from covid-19. Independent task force report \# 78. October 2020. https://www.cfr.org/report/pandemic-preparedness-lesso ns-COVID-19/findings/.

2. Hemenway D. Why don't we spend enough on public health?. N Engl J Med. 2010;362:1657-8.

3. Hemenway D. While we were sleeping: success stories in injury and violence prevention. Berkeley: University of California Press; 2009.

4. Veblen T. The theory of the leisure class. New York: MacMillan; 1899.

5. Frank RH. Choosing the right pond: human behavior and the quest for status. New York: Oxford University Press; 1985.

6. Solnick SJ, Hemenway D. Are positional concerns stronger in some domains than in others? AEA Pap Proc. 2005;95:147-51.

7. Wouters S, van Exel NJA, Van de Donk M, Rohde KIM, Brouwer WBF. Do people desire to be healthier than other people? A short note positional concerns for health. Eur J Health Econ. 2015;16:47-54.

Publisher's Note Springer Nature remains neutral with regard to jurisdictional claims in published maps and institutional affiliations. 